\title{
УДК: 004.738.5:005
}

\section{МЕТРИКИ ЦИФРОВОЇ ТРАНСФОРМАЦІЇ БІЗНЕСУ: СВІТОВІ ТА ВІТЧИЗНЯНІ РЕАЛІЇ}

\author{
Ірина Струтинська
}

\author{
Тернопільський нащіональний технічний університет імені Івана Пулюя, \\ Тернопіль, Україна
}

\begin{abstract}
Резюме. Досліджено основні глобальні метрики оцінювання розвитку циифрової економіки $в$ країнах CC, а саме: Індекс глобальної конкурентоспроможності (Global Coтреtitiveness Index (GCI (WEF); Глобальний інноваиійний індекс (Global Innovation Index (GII); Індекс мережевої готовності (Networked Readiness Index (NRI (WEF); Індекс «Широкосмугового доступу до Iнтернету» (Broadband Penetration Index (ITU); «Iндекс ичирової конкурентоспроможності» (World Digital Competitiveness (WDC) ranking); Свропейський звіт про ичирровий прогрес» (European Digital Progress Report); «Iндекс uииррової економіки та суспільства» (Digital Economy and Society Index (DESI, IDESI (EU), наведено їх характеристику та складові. Проведено аналітику щуодо визначення позицій нашої краӥни у відповідних дослідженнях. 3'ясовано, щзо Україна посідає низьке місие в економічному процвітанні, управлінні. 3'ясовано, щзо відносно непогані позииії Україна посідає в напрямках відкриття бізнесу, отримання кредитів, свободи міжнародної торгівлі, а також освіти та соціального капіталу. Досліджено, щчо в глобальному контексті Украӥна ще не відіграє провідної ролі на світовому ринку, проте вже займає помітне місие у світовій системі координат, передусім, завдяки стратегічному розташуванню. 3'ясовано, щзо зниження позицій країни в міжнародних рейтингах пов'язане з нестабільною політичною, соціально-економічною ситуацією, корупиією, некомпетентністю влади. Доведено, щзо пошук шляхів підвищення конкурентних позицій краӥни шляхом цุифрового розвитку в світовому економічному просторі є одним із найактуальніших завдань украйнського уряду. Проведено глибинний аналіз метрик оиінювання ичирової трансформації бізнес-структур та надано пропозиції щуодо необхідності розроблення індексів, індикаторів і методик оцінювання циифрового розвитку вітчизняних бізнес-структур.
\end{abstract}

Ключові слова: циифровізація, ичифрова економіка, ичифрова трансформація бізнесу, Індекс цчифрової економіки та суспільства, Індекс ичифрової інтенсивності.

\section{METRICS OF DIGITAL BUSINESS TRANSFORMATION: WORLD AND NATIONAL REALITIES}

\author{
Iryna Strutynska
}

\section{Ternopil Ivan Puluj National Technical University, Ternopil, Ukraine}

Summary. The paper deals with the main global metrics for assessing the development of the digital economy in EU countries, such as: Global Competitiveness Index (GCI (WEF); Global Innovation Index (GII); Networked Readiness Index (NRI) (WEF); Broadband Penetration Index (ITU); World Digital Competitiveness Index (WDC) ranking; European Digital Progress Report; European Digital Progress Report; economy and society (Digital Economy and Society Index (DESI, IDESI (EU), their characteristics and components are presented. The analytics concerning the determination of our country position in relevant investigations is carried out. It is defined that Ukraine ranks low in economic prosperity and management. It is revealed that Ukraine ranks high in the areas of business opening, obtaining of credits, freedom of international trade, as well as education 
and social capital. It is investigated that in the global context Ukraine does not play the leading role in the world market, but it occupies a prominent place in the global coordinate system, primarily due to its strategic location.

It is revealed that the country's decline in international rankings is related to unstable political, socioeconomic situation, corruption, incompetence of the authorities. It is proved that looking for the ways to increase the country's competitive position through digital development in the world economic space is one of the most important tasks of Ukrainian government. In-depth analysis of the metrics for assessing the digital transformation of business structures is carried out and suggestions concerning the need of development the indices, indicators and methods for assessing the digital development of domestic business structures are made.

Key words: digitalization, digital economy, digital business transformation, Digital Economy and Society Index (DESI), Digital Intensity Index.

Постановка проблеми. В епоху стрімкого розвитку інформаційнокомунікаційних технологій та інновацій важливого значення набувають процеси цифровізації. Україна також стала на шлях цифровізації, про що свідчить прийняття у 2018 році Концепції розвитку цифрової економіки й суспільства України на 20182020 роки та затвердженому плані заходів щодо ï реалізації [1]. У даному документі йдеться про розвиток цифрової економіки України, який полягає у створенні ринкових стимулів, мотивацій, попиту та формуванні потреб щодо використання цифрових технологій, продуктів і послуг серед українських секторів промисловості, сфер життєдіяльності, бізнесу та суспільства.

Реалізація плану заходів щодо реалізації Концепції розвитку цифрової економіки та суспільства України на 2018-2020 роки передбачає: запровадження використання сучасної термінології у цифровій сфері відповідно до європейських практик; визначення індексів, індикаторів та методики оцінювання цифрового розвитку України відповідно до міжнародних практик; розроблення пропозиції щодо впровадження базових цифрових послуг для використання громадянами у сфері освіти, зокрема, розроблення «дорожніх карт» цифрових трансформацій та відповідних цифрових платформ; забезпечення широкосмугового доступу до Інтернету; розвиток цифрових компетенцій та навичок громадян [2].

Аналіз останніх досліджень i публікацій. Питання розвитку діджиталекономіки висвітлені в працях таких зарубіжних дослідників, як В. Айзексон, Б. Ларралде, А. Тоффлер, Х. Тоффлер, Р. Хаген, А. Швієнбахер, Т. Шольц. До обгрунтування понятійного апарату діджитал-економіки долучилися також вітчизняні фахівці, зокрема Ю. М. Бажал, К. Ю. Кононова, Н. М. Краус. Проте питання цифрової трансформації бізнес-структур, а саме методикам розрахунку індексу цифрової трансформації бізнесу не приділено достатньо уваги.

Метою дослідження $є$ структурування основних глобальних метрик оцінювання розвитку цифрової економіки в країнах ЄС та України й глибинний аналіз метрик оцінювання цифрової трансформації бізнес-структур.

Постановка завдання. Дослідити основні глобальні метрики розвитку цифрової економіки в країнах ЄС. Проаналізувати, які позиції нашої країни у відповідних дослідженнях. Визначити метрики, які використовують для розрахунку цифрової трансформації бізнесу та надати пропозиції щодо необхідності розроблення індексів, індикаторів та методи оцінювання цифрового розвитку бізнес-структур.

Виклад основного матеріалу. Основними метриками оцінювання розвитку цифрової економіки в країнах ЄС є ряд глобальних індексів, які на основі певних статистичних методологій і спостережень відображають рівень розвитку цифрової економіки в різних країнах. Серед таких інструментів можна виокремити найбільш глобальні (табл. 1). 


\section{Таблиця 1}

Глобальні статистичні методології, які відображають рівень розвитку країни

Table 1

Global statistical methodologies reflecting the country development level

\begin{tabular}{|c|c|c|}
\hline $\begin{array}{l}\text { № } \\
\text { 3/ח }\end{array}$ & Назва статистичної методології & $\begin{array}{c}\text { Позиція } \\
\text { України у } \\
2018 \text { році }\end{array}$ \\
\hline \multicolumn{3}{|c|}{ Індекси I групи: Глобальні індекси, які відображають загальний рівень розвитку країни } \\
\hline 1 & $\begin{array}{l}\text { Індекс глобальної конкурентоспроможності (Global Competitiveness Index } \\
\text { (GCI (WEF) [3] }\end{array}$ & $81(137)$ \\
\hline 2 & Глобальний інноваційний індекс (Global Innovation Index (GII) [4] & $43(143)$ \\
\hline \multicolumn{3}{|c|}{$\begin{array}{c}\text { Індекси II групи: Глобальні індекси, які відображають рівень технічної інфраструктури } \\
\text { для ефективного розвитку бізнесу та країни }\end{array}$} \\
\hline 3 & Індекс мережевої готовності (Networked Readiness Index (NRI (WEF) [5] & $64(139)$ \\
\hline 4 & $\begin{array}{l}\text { Індекс «Широкосмугового доступу до Інтернету» (Broadband Penetration } \\
\text { Index (ITU) [6] }\end{array}$ & \\
\hline \multicolumn{3}{|c|}{ Індекси III групи: Глобальні індекси, які відображають рівень цифрового розвитку країни } \\
\hline 5 & $\begin{array}{llll}\text { «Індекс цифрової } & \text { конкурентоспроможності» } & \text { (World } & \text { Digital } \\
\text { Competitiveness (WDC) ranking) [7] } & & \end{array}$ & $58(63)$ \\
\hline 6 & $\begin{array}{l}\text { «Європейський звіт про цифровий прогрес» (European Digital Progress } \\
\text { Report) [8] }\end{array}$ & - \\
\hline 7 & $\begin{array}{l}\text { «Індекс цифрової економіки та суспільства» (Digital Economy and Society } \\
\text { Index (DESI, IDESI (EU) [8] }\end{array}$ & - \\
\hline
\end{tabular}

До індексів I групи належать: Індекс глобальної конкурентоспроможності (Global Competitiveness Index (GCI (WEF) та Глобальний інноваційний індекс (Global Innovation Index (GII).

Індекс глобальної конкурентоспроможності складений із 113 змінних, які детально характеризують конкурентоспроможність країн світу, що знаходяться на різних рівнях економічного розвитку. Сукупність змінних на дві третини складається 3 результатів глобального опитування керівників компаній (щоб охопити широке коло факторів, які впливають на бізнес-клімат у досліджуваних країнах), а на одну третину iз загальнодоступних джерел (статистичні дані й результати досліджень, що здійснюються на регулярній основі міжнародними організаціями). Всі змінні об'єднані в 12 контрольних показників, які визначають національну конкурентоспроможність: якість інститутів; інфраструктура; макроекономічна стабільність; здоров'я і початкова освіта; вища освіта й професійна підготовка; ефективність ринку товарів і послуг; ефективність ринку праці; розвиненість фінансового ринку; рівень технологічного розвитку; розмір внутрішнього ринку; конкурентоспроможність компаній; інноваційний потенціал.

Вони, у свою чергу, організовані в три субіндекси відповідно до трьох основних етапів розвитку: основні вимоги, підсилювачі ефективності, фактори інновації та складності. Ці три субіндекси мають різну вагу в розрахунку загального індексу залежно від стадії розвитку кожної економіки, наближеного до ВВП на душу населення та частки експорту мінеральної сировини.

У 2018 році Україна посіла 81-е місце серед 137 країн світу, покращивши свої позиції на чотири пункти. Проте у деяких показниках значно погіршила свої позиції.

Саме тому негативними факторами для ведення бізнесу в нашій країні визначено: інфляцію, корупцію, політичну нестабільність, високі податкові ставки, складність 
податкового законодавства, нестабільність урядів, ускладнений доступ до фінансів, неефективну державну бюрократію, регулювання валютного ринку, недостатню освіченість працівників, погану етику робочої сили, недостатню здатність до інновацій, обмежувальне регулювання ринку праці, невідповідну якість інфраструктури, злочинність та крадіжки, низьку якість охорони здоров'я.

Наступний глобальний індекс, що відноситься до першої групи (табл. 2) та який варто проаналізувати, це Глобальний інноваційний індекс (Global Innovation Index (GII).

Друга група індексів (табл. 1) відображає стан інфраструктури для ефективного розвитку економіки (цифрової економіки).

«Індекс мережевої готовності» (Networked Readiness Index (NRI (WEF). За допомогою Індексу мережевої готовності оцінюються рушійні чинники і ступінь впливу мережевої готовності й можливостей ІКТ у країні. При цьому враховується рівноправна роль і відповідальність усіх «гравців» соціуму - індивідуумів (громадськості), бізнесу й уряду. Оцінювання країн за цим показником проводиться Всесвітнім економічним форумом (World Economic Forum) з 2002 року. Результати України упродовж п'яти років не зовсім позитивні. У 2013 році 73 (144), а у 2017 році 64 (139). Наша країна не змогла продемонструвати високих позицій у відповідному Індексі, а позитивна динаміка відбулася лише за рахунок зміни значень Індексу, викликану, в першу чергу, змінами в структурі методології, але ніяк не підкріплена фундаментальними змінами в розвитку інформаційно-комунікаційних технологій у країні.

Наступний індекс цієї підгрупи, це «Індекс широкосмугового доступу до Інтернету» (Broadband Penetration Index (ITU). Окрім високої швидкості, широкосмуговий доступ забезпечує безперервне підключення до Інтернету (без необхідності встановлення комутованого з'єднання) і так званий «двосторонній» зв'язок, тобто можливість як приймати («завантажувати»), так і передавати («вивантажувати») інформацію на високих швидкостях. Широкосмуговий доступ не лише забезпечує багатство інформаційного наповнення («контенту») й послуг, але й перетворить весь Інтернет як у плані пропонованого мережею сервісу, так і в плані ії використання. Позиція України низька, й потребує вдосконалення показників (табл. 2).

\section{Таблиця 2}

Значення показників, що характеризують рівень використання широкосмугового доступу до Інтернету в Україні

Table 2

Values of indicators characterizing the level of broadband Internet access in Ukraine

\begin{tabular}{|c|l|c|}
\hline $\begin{array}{c}\text { № } \\
3 / \Pi\end{array}$ & \multicolumn{1}{|c|}{ Показники } & Значення \\
\hline 1 & Перелік національних широкосмугових політик (2018) & Відсутні \\
\hline 2 & Відсоток осіб, які користуються Інтернетом (2017) & $53,0 \%$ \\
\hline 3 & Фіксовані широкосмугові підписки на 100 жителів України (2017) & $12,6 \%$ \\
\hline 4 & Мобільні широкосмугові підписки на 100 жителів (2017) & $41,7 \%$ \\
\hline
\end{tabular}

До індексів III групи (індекси, які відображають рівень цифрового розвитку країни) належать: «Індекс цифрової конкурентоспроможності» (World Digital Competitiveness (WDC) ranking); «Свропейський звіт про цифровий прогрес» (European Digital Progress Report); «Індекс цифрової економіки та суспільства» (Digital Economy and Society Index (DESI, IDESI (EU). 
«Індекс цифрової конкурентоспроможності» (World Digital Competitiveness (WDC) ranking). Це новий рейтинг (2016), що доповнює загальний рейтинг «Індекс глобальної конкурентоспроможності» (Global Competitiveness Index (GCI (WEF). Даний індекс відображає краще розуміння зусиль, які були вкладені в розвиток цифрової економіки, а також відображає ефекти, спричинені внеском цифрових технологій на ефективність країни та надає можливість оцінювати й керувати цифровими перетвореннями. Мета відповідного Індексу - це оцінювання того, якою мірою країна досліджує та імплементує цифрові технології, що ведуть до трансформацій у практиці уряду, бізнес-моделей та суспільства в цілому. Позиція України в даному рейтингу 58 із 63 країн, які були досліджені в рамках даного дослідження.

Основним інструментом оцінювання розвитку цифрової економіки і суспільства в $€ C$ є так зване цифрове табло, яке складається з понад 150 показників, що відображають різні аспекти цифрового розвитку, зокрема - проникнення Інтернету, розвиток цифрових навичок, цифровізацію бізнесу та державних (публічних) послуг тощо.

DESI було розроблено відповідно до керівних принципів та рекомендацій організації економічного співробітництва й розвитку (ОЕСР, Organization for Economic Co-operation and Development)-міжнародна організація, що об'єднує 35 високорозвинених країн світу. Джерелом даних для формування цього цифрового табло $\epsilon$ опитування статистичних служб Європейської Комісії (Євростату та DG CNECT) щодо використання інформаційно-комунікаційних технологій (IКT) серед домогосподарств та підприємств різної форми власності. Також дані збирають із спеціальних досліджень, які запущені службами Європейської Комісії. Дані щодо широкосмугового доступу до Інтернету отримуються від провайдерів.

На основі цифрового табло формуються два ключових звіти щодо стану цифрової економіки в $€ C$, зокрема Індекс цифрової економіки та інформаційного суспільства (DESI) та Європейський звіт з цифрового прогресу (EDRP). Відмінність між ними полягає у тому, що EDPR більше акцентує увагу на цифровий розвиток окремої країни, зокрема зміни у законодавстві тощо. При цьому використовуються як дані цифрового табло, так і національне законодавство. Водночас DESI надає узагальнене уявлення про цифровий розвиток у країнах-членах $Є С$ на основі переважно статистичних даних та охоплює інформацію щодо таких аспектів: доступ до широкосмугового Інтернету та його якість; цифрові навички та людський капітал; використання IКТ громадянами; використання цифрових технологій бізнесом; цифрові публічні послуги.

Загалом Індекс цифрової економіки та інформаційного суспільства (DESI) має тришарову структуру. Він структурований із 5 основних факторів, що розділені на субфактори, які, в свою чергу, складаються з індивідуальних показників (табл. 3).

\section{Таблиця 3}

Структура індексу цифрової економіки та інформаційного суспільства (DESI)

Table 3

Digital economy and information society (DESI) structure

\begin{tabular}{|c|c|c|}
\hline Фактор & Субфактор & Індикатор \\
\hline 1 & 2 & 3 \\
\hline \multirow{3}{*}{ 1. 3'єднання } & $\begin{array}{c}\text { 1а Фіксований } \\
\text { широкосмуговий }\end{array}$ & 1a1 Фіксоване широкосмугове покриття \\
\cline { 2 - 3 } & & 1a2 Фіксована широкосмугова передача \\
\hline
\end{tabular}




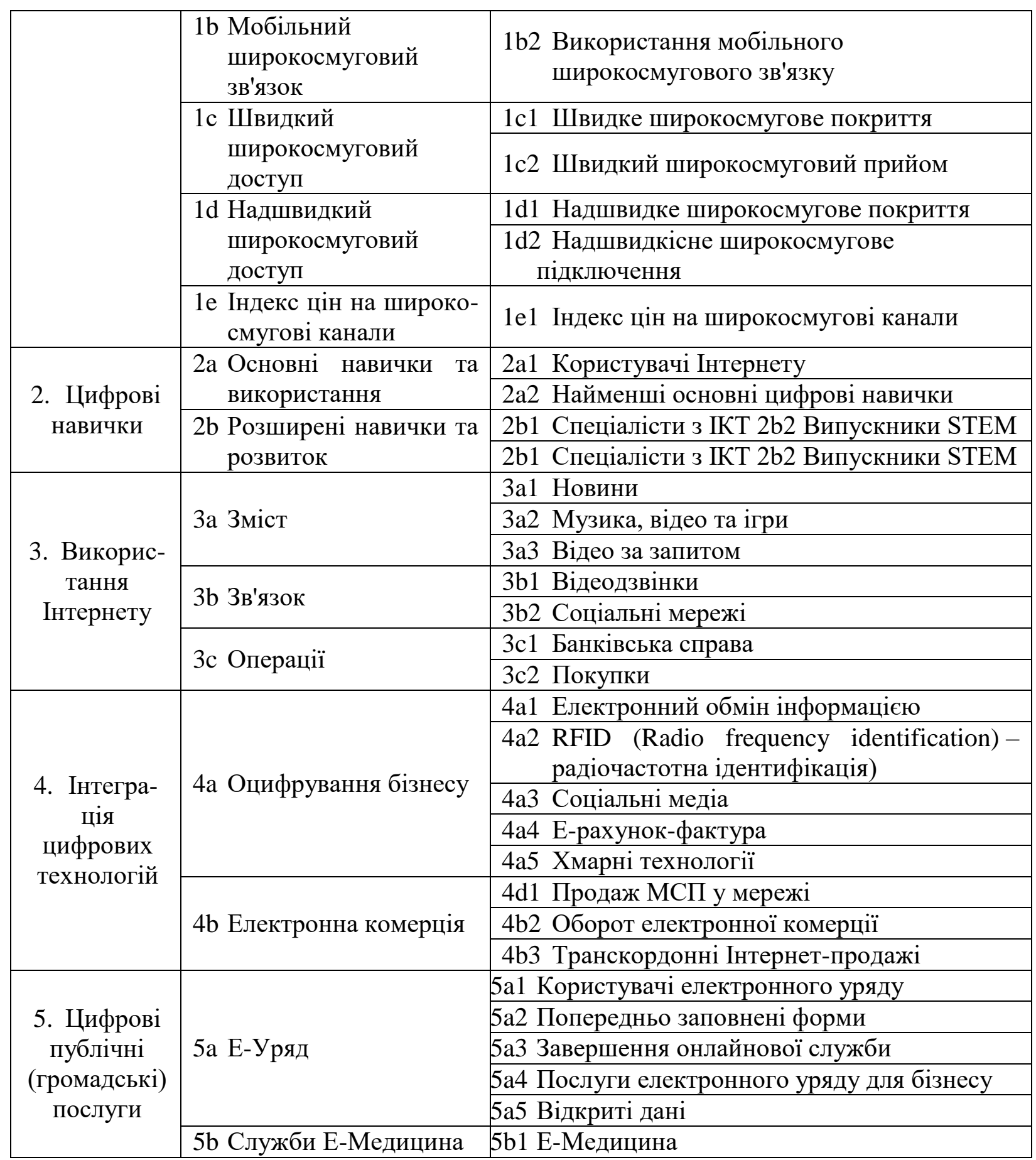

Для того, щоб агрегувати показники, виражені в різних одиницях, у підрозділи та розміри DESI, ці показники були нормалізовані. B DESI, нормалізацію виконано методом min-max, який складається 3 лінійної проекції кожного індикатора на шкалі від 0 до 1. Для індикаторів з позитивним напрямком (тобто де вище, краще), значення 0 у нормалізованому масштабі прив'язували до мінімуму значення в індикаторному вихідному масштабі, а значення 1 у нормованому масштабі були прив'язані до максимального значення в шкалі індикатора. Для забезпечення міжчасових порівнянь показників індексів, мінімумів і максимумів нормалізація кожного індикатора була фіксованою й буде використана для нормалізації в майбутній версії DESI.

У таблиці 4 наведено загальні ваги основних факторів DESI, прийняті в рамках цифрових політик ЄС. 


\section{Таблиця 4}

Ваги індикаторів основних факторів DESI

Table 4

Scales of indicators of the main DESI factors

\begin{tabular}{|c|l|c|}
\hline $\begin{array}{c}\text { № } \\
\text { 3/п }\end{array}$ & \multicolumn{1}{|c|}{ Розмір } & Вага \\
\hline 1 & Підключення & $25 \%$ \\
\hline 2 & Людський капітал & $25 \%$ \\
\hline 3 & Використання Інтернет-послуг & $15 \%$ \\
\hline 4 & Інтеграція цифрових технологій & $20 \%$ \\
\hline 5 & Цифрові публічні (громадські) послуги & $15 \%$ \\
\hline
\end{tabular}

$$
\operatorname{DESI}(C)=3(C) * 0.25+\text { ЛК }(C) * 0.25+\mathrm{IP}(C) * 0.15+Ц \mathrm{~T}(C) * 0.2+Ц \Pi(C) * 0.15
$$

де складова $(C)$ - оцінка, отримана країною С у певному вимірі;

«3» (зв'язок) і «Л» (людський капітал) можна вважати найбільш важливими та ваговими факторами, тому що вони відображають інфраструктурний стан цифрової економіки й суспільства. Саме тому даним факторам надано найбільшу вагу.

Фактору «Інтеграція цифрових технологій» (ЦТ) надано також високу вагу, адже цей показник фіксує використання першого показника, а саме використання ІКТ у бізнессекторі, що $\epsilon$ однією 3 найважливіших чинників зростання економіки країни. «Використання Інтернет-послуг (громадянами)» (IP) i «Цифрові публічні (громадські) послуги» (ЦП) забезпечуються якістю першого фактора, а саме інфраструктурою, їхній внесок змінюється й взаємозалежний від факторів «Зв'язок» і «Людський капітал». 3 цієї причини їм було присвоєно меншу вагову оцінку.

У свою чергу, діапазони вагових оцінок також присвоєні кожному із субфакторів, які сумарно по кожному фактору дорівнюють 100\% (табл. 5).

\section{Таблиця 5}

Ваги субфакторів DESI

Table 5

Scales of DESI subfactors

\begin{tabular}{|c|l|c|}
\hline $\begin{array}{c}\text { № } \\
\text { 3/п }\end{array}$ & \multicolumn{1}{|c|}{ Субфактор } & Вага \\
\hline 1 & \multicolumn{1}{|c|}{2} & 3 \\
\hline $\mathbf{1}$ & Підключення & $20 \%$ \\
\hline $1 \mathrm{a}$ & Фіксований широкосмуговий зв'язок & $30 \%$ \\
\hline $1 \mathrm{~b}$ & Мобільний широкосмуговий & $20 \%$ \\
\hline $1 \mathrm{c}$ & Швидкий широкосмуговий зв'язок & $20 \%$ \\
\hline $1 \mathrm{~d}$ & Ультрашвидкий широкосмуговий & $10 \%$ \\
\hline $1 \mathrm{e}$ & Індекс цін широкосмугового зв'язку & \\
\hline $\mathbf{2}$ & Людський капітал & $50 \%$ \\
\hline $2 \mathrm{a}$ & Основні навички та використання & $50 \%$ \\
\hline $2 \mathrm{~b}$ & Передові навички та розвиток & \\
\hline
\end{tabular}


Закінчення таблиці 5

\begin{tabular}{|c|l|c|}
\hline 1 & \multicolumn{1}{|c|}{2} & 3 \\
\hline $\mathbf{3}$ & Використання Інтернет-послуг & \\
\hline $3 \mathrm{a}$ & Контент & $33 \%$ \\
\hline $3 \mathrm{~b}$ & Комунікації & $33 \%$ \\
\hline $3 \mathrm{c}$ & Операції & $33 \%$ \\
\hline $\mathbf{4}$ & Інтеграція цифрових технологій & $60 \%$ \\
\hline $4 \mathrm{a}$ & Оцифрування бізнесу & $40 \%$ \\
\hline $4 \mathrm{~b}$ & Е-комерція & \\
\hline $\mathbf{5}$ & Цифрові публічні (громадські) послуги \\
\hline $5 \mathrm{a}$ & еУрядт & $80 \%$ \\
\hline $5 \mathrm{~b}$ & еЗдоров'я & $20 \%$ \\
\hline
\end{tabular}

Коли йдеться про інтеграцію цифрових технологій у бізнес-сектор, то вимір бізнес-оцифрування $\epsilon$ важливішим, ніж електронна комерція, а, отже, зважений на $60 \%$.

Розглянемо детальніше показники (індикатори), що входять до фактора № 4 «Інтеграція цифрових технологій» та субфакторів «Цифровий бізнес» та «Е-комерція» (табл. 6).

\section{Таблиця 6}

Складові показники (індикатори), що входять до фактора № 4 «Інтеграція цифрових технологій бізнесом» та субфакторів «Цифровий бізнес» та «Е-комерція»

Table 6

Complex indices (indicators) included in factor № 4 «Integration of digital technologies by business» and subfactors «Digital business» and «E-commerce»

\begin{tabular}{|c|c|}
\hline E-commerce & Оцифровка бізнесу \\
\hline 1 & 2 \\
\hline $\begin{array}{l}\text { Підприємство продає більше } 50 \% \\
\text { через вебсайт чи додаток }\end{array}$ & $\begin{array}{l}\text { Інтеграція (автоматизація) внутрішніх процесів } \\
\text { (ERP-system) Планування ресурсів підприємства) }\end{array}$ \\
\hline Продаж через маркетплейс & $\begin{array}{l}\text { Інтеграція (автоматизація) внутрішніх процесів } \\
\text { (ERP-system) Планування ресурсів підприємства) }\end{array}$ \\
\hline $\begin{array}{l}\text { Підприємство продає через власний } \\
\text { веб-сайт чи додаток }\end{array}$ & $\begin{array}{l}\text { Використання аналітичних (CRM-систем), } \\
\text { управління взаємовідносинами із клієнтами) }\end{array}$ \\
\hline $\begin{array}{l}\text { Продажі через власний веб-сайт чи } \\
\text { додаток }\end{array}$ & Електронне управління ланцюгами поставок \\
\hline $\begin{array}{l}\text { Підприємство продає через } \\
\text { Е-комерційний маркет плейс }\end{array}$ & $\begin{array}{l}\text { Підприємства, що відправляють електронні } \\
\text { рахунки-фактури }\end{array}$ \\
\hline $\begin{array}{l}\text { Підприємство продає більше 25\% } \\
\text { через веб-сайт чи додаток }\end{array}$ & $\begin{array}{l}\text { Підприємства володіють веб-сайтом або } \\
\text { домашньою сторінкою }\end{array}$ \\
\hline $\begin{array}{l}\text { Замовлення товарів чи сервіси } \\
\text { онлайн }\end{array}$ & $\begin{array}{l}\text { Підприємства володіють веб-сайтом, що мають } \\
\text { спеціальні налаштування (SEO) }\end{array}$ \\
\hline Кордон Е-комерції & $\begin{array}{l}\text { Підприємства, що надають працівникам } \\
\text { віддалений доступ до IT-систем }\end{array}$ \\
\hline Купівля: фізичних товарів онлайн & $\begin{array}{l}\text { Підприємства, що забезпечують більше } 20 \% \text { своїх } \\
\text { працівників портативними пристроями }\end{array}$ \\
\hline Купівля: сервісів онлайн & $\begin{array}{l}\text { Підприємства, що самостійно забезпечують усіх } \\
\text { своїх працівників портативними пристроями }\end{array}$ \\
\hline
\end{tabular}


Закінчення таблиці 6

\begin{tabular}{|l|l|}
\hline \multicolumn{1}{|c|}{1} & \multicolumn{1}{|c|}{2} \\
\hline Купівля: контенту онлайн & $\begin{array}{l}\text { Підприємства, що використовують мобільний } \\
\text { Інтернет для запуску бізнес-додатків }\end{array}$ \\
\hline $\begin{array}{l}\text { Продаж онлайн (наприклад, через } \\
\text { аукціон) }\end{array}$ & $\begin{array}{l}\text { Підприємства, що платять кошти за рекламу в } \\
\text { Інтернеті }\end{array}$ \\
\hline $\begin{array}{l}\text { Індивідуми, хто не мав проблем при } \\
\text { купівлі/замовленні товарів чи } \\
\text { сервісів більше через Інтернет, аніж } \\
\text { у приватних осіб }\end{array}$ & $\begin{array}{l}\text { Підприємства, з високим рівнем цифрової } \\
\text { інтенсивності }\end{array}$ \\
\hline Продаж онлайн підприємствами & $\begin{array}{l}\text { Підприємства, 3 дуже низьким рівнем цифрової } \\
\text { інтенсивності }\end{array}$ \\
\hline Обороти Е-комерції & $\begin{array}{l}\text { Оцінювання цифрової інтенсивності для } \\
\text { підприємства }\end{array}$ \\
\hline $\begin{array}{l}\text { Підприємства, що продають } \\
\text { закордон іншим країнам ЄС }\end{array}$ & $\begin{array}{l}\text { Використання технологій радіочастотної } \\
\text { ідентифікації (RFІD) }\end{array}$ \\
\hline $\begin{array}{l}\text { Підприємства, які використовують } \\
\text { В2С можливості Інтернет-продажів }\end{array}$ & $\begin{array}{l}\text { Підприємства, що використовують соціальні } \\
\text { мережі }\end{array}$ \\
\hline & $\begin{array}{l}\text { Підприємства, що використовують дві або більше } \\
\text { соціальних мереж }\end{array}$ \\
\hline & Підприємства, що використовують хмарні сервіси \\
\hline
\end{tabular}

Зі збиранням даних з відповідної групи № 4 «Використання цифрових технологій бізнесом» виникають найбільші труднощі, адже бізнес не завжди охочий відкривати власні дані. I загалом, необхідно постійно відстежувати, як поява нових цифрових технологій інтегрується у сферу бізнесу.

Значення індексу цифрової інтенсивності (табл. 7) становить від 0 до 12 балів.

Підприємства, що мають дуже низький індекс цифрової інтенсивності (оцінка від 0 до 3 балів), підприємства, що мають низький індекс цифрової інтенсивності (оцінка від 4 до 6 балів), підприємства, що мають високий індекс цифрової інтенсивності (оцінка від 7 до 9 балів), підприємства, що мають дуже високий індекс цифрової інтенсивності (оцінка від 10 до 12 балів).

\section{Таблиця 7}

Складові індикатори індексу цифрової інтенсивності (2015-2018рр.)

Table 7

Components of the Digital Intensity Index (2015-2018)

\begin{tabular}{|c|c|c|c|c|c|}
\hline № & 2015 & 2016 & 2017 & 2018 & 2019 \\
\hline 1 & 2 & 3 & 4 & 5 & 6 \\
\hline 1 & $\begin{array}{l}\text { Підприємства, де } \\
\text { більше 50\% осіб } \\
\text { використовували } \\
\text { комп'ютери } 3 \text { до- } \\
\text { ступом до Інтер-нету } \\
\text { в комерцій-них цілях }\end{array}$ & $\begin{array}{l}\text { Підприємства, де } \\
\text { більше 50\% осіб } \\
\text { використовували } \\
\text { комп'ютери } 3 \text { до- } \\
\text { ступом до Інтер- } \\
\text { нету в комерцій- } \\
\text { них цілях }\end{array}$ & $\begin{array}{l}\text { Підприємства, де } \\
\text { більше 50\% осіб } \\
\text { використовували } \\
\text { комп'ютери } 3 \text { до- } \\
\text { ступом до Інтер- } \\
\text { нету в комерцій- } \\
\text { них цілях }\end{array}$ & $\begin{array}{l}\text { Підприємства, де } \\
\text { більше 50\% осіб } \\
\text { використовували } \\
\text { комп'ютери } 3 \text { до- } \\
\text { ступом до Інтер- } \\
\text { нету в комерцій- } \\
\text { них цілях }\end{array}$ & $\begin{array}{l}\text { Підприємства, де } \\
\text { більше 50\% осіб } \\
\text { використовували } \\
\text { комп'ютери } 3 \text { до- } \\
\text { ступом до Інтер- } \\
\text { нету в комерцій- } \\
\text { них цілях }\end{array}$ \\
\hline 2 & $\begin{array}{l}\text { Використовують } \\
\text { власних спеціалістів } 3 \\
\text { ІКТ або послуги } \\
\text { зовнішніх } \\
\text { спеціалістів }\end{array}$ & $\begin{array}{l}\text { Використовують } \\
\text { власних спеціа- } \\
\text { лістів } 3 \text { ІКТ або } \\
\text { послуги зовніш- } \\
\text { ніх спеціалістів }\end{array}$ & $\begin{array}{l}\text { Власні IKT спе- } \\
\text { ціалісти* }\end{array}$ & $\begin{array}{l}\text { Власні IKT спе- } \\
\text { ціалісти }\end{array}$ & $\begin{array}{l}\text { Власні IКТ спе- } \\
\text { ціалісти }\end{array}$ \\
\hline
\end{tabular}


Продовження таблиці 7

\begin{tabular}{|c|c|c|c|c|c|}
\hline 1 & 2 & 3 & 4 & 5 & 6 \\
\hline 3 & $\begin{array}{l}\text { Швидкий широ- } \\
\text { космуговий Інте-рнет } \\
\text { (30 Мбіт/с або вище) }\end{array}$ & $\begin{array}{l}\text { Швидкий широ- } \\
\text { космуговий Інте- } \\
\text { рнет (30 Мбіт/с } \\
\text { або вище) }\end{array}$ & $\begin{array}{l}\text { Швидкий широ- } \\
\text { космуговий Інте- } \\
\text { рнет (30 Мбіт/с } \\
\text { або вище) }\end{array}$ & $\begin{array}{l}\text { Швидкий широ- } \\
\text { космуговий Інте- } \\
\text { рнет (30 Мбіт/с } \\
\text { або вище) }\end{array}$ & $\begin{array}{l}\text { Швидкий широ- } \\
\text { космуговий Інте- } \\
\text { рнет (30 Мбіт/с } \\
\text { або вище) }\end{array}$ \\
\hline 4 & $\begin{array}{l}\text { Мобільні } \text { інтер-нет- } \\
\text { пристрої для не } \\
\text { менше } 20 \% \text { зайнятих } \\
\text { осіб (для ділового } \\
\text { спілкування) }\end{array}$ & $\begin{array}{l}\text { Мобільні інтер- } \\
\text { нет-пристрої для } \\
\text { не менше } 20 \% \\
\text { зайнятих осіб } \\
\text { (для ділового } \\
\text { спілкування) }\end{array}$ & $\begin{array}{l}\text { Мобільні інтер- } \\
\text { нет-пристрої для } \\
\text { не менше } 20 \% \\
\text { зайнятих осіб } \\
\text { (для ділового } \\
\text { спілкування) }\end{array}$ & $\begin{array}{l}\text { Мобільні інтер- } \\
\text { нет-пристрої для } \\
\text { не менше } 20 \% \\
\text { зайнятих осіб } \\
\text { (для ділового } \\
\text { спілкування) }\end{array}$ & $\begin{array}{l}\text { Мобільні інтер- } \\
\text { нет-пристрої для } \\
\text { не менше } 20 \% \\
\text { зайнятих осіб } \\
\text { (для ділового } \\
\text { спілкування) }\end{array}$ \\
\hline 5 & ають веб-сайт & Мають веб-сайт & Мають веб-сайт & Мають веб-сайт & Мають веб-сайт \\
\hline 6 & 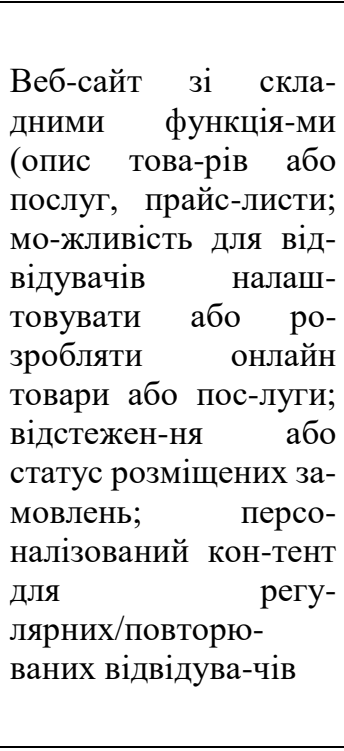 & $\begin{array}{l}\text { Веб-сайт зі скла- } \\
\text { дними функція- } \\
\text { ми (опис това-рів } \\
\text { або послуг, } \\
\text { прайс-листи; мо- } \\
\text { жливість для від- } \\
\text { відувачів налаш- } \\
\text { товувати або ро- } \\
\text { зробляти онлайн } \\
\text { товари або пос- } \\
\text { луги; відстежен- } \\
\text { ня або статус } \\
\text { розміщених за- } \\
\text { мовлень; персо- } \\
\text { налізований кон- } \\
\text { тент для регу- } \\
\text { лярних/повторю- } \\
\text { ваних відвідува- } \\
\text { чів }\end{array}$ & $\begin{array}{l}\text { Веб-сайт зі скла- } \\
\text { дними функція- } \\
\text { ми (опис това-рів } \\
\text { або послуг, } \\
\text { прайс-листи; мо- } \\
\text { жливість для від- } \\
\text { відувачів налаш- } \\
\text { товувати або ро- } \\
\text { зробляти онлайн } \\
\text { товари або пос- } \\
\text { луги; відстежен- } \\
\text { ня або статус } \\
\text { розміщених за- } \\
\text { мовлень; персо- } \\
\text { налізований кон- } \\
\text { тент для регу- } \\
\text { лярних/повторю- } \\
\text { ваних відвідува- } \\
\text { чів }\end{array}$ & $\begin{array}{l}\text { Веб-сайт зі скла- } \\
\text { дними функція- } \\
\text { ми (опис това-рів } \\
\text { або послуг, } \\
\text { прайс-листи; мо- } \\
\text { жливість для від- } \\
\text { відувачів налаш- } \\
\text { товувати або ро- } \\
\text { зробляти онлайн } \\
\text { товари або пос- } \\
\text { луги; відстежен- } \\
\text { ня або статус } \\
\text { розміщених за- } \\
\text { мовлень; персо- } \\
\text { налізований кон- } \\
\text { тент для регу- } \\
\text { лярних/повторю- } \\
\text { ваних відвідува- } \\
\text { чів }\end{array}$ & $\begin{array}{l}\text { Веб-сайт зі скла- } \\
\text { дними функція- } \\
\text { ми (опис това-рів } \\
\text { або послуг, } \\
\text { прайс-листи; мо- } \\
\text { жливість для від- } \\
\text { відувачів налаш- } \\
\text { товувати або ро- } \\
\text { зробляти онлайн } \\
\text { товари або пос- } \\
\text { луги; відстежен- } \\
\text { ня або статус } \\
\text { розміщених за- } \\
\text { мовлень; персо- } \\
\text { налізований кон- } \\
\text { тент для регу- } \\
\text { лярних/повторю- } \\
\text { ваних відвідува- } \\
\text { чів }\end{array}$ \\
\hline 7 & $\begin{array}{l}\text { Використання } \\
\text { соціальних медіа }\end{array}$ & $\begin{array}{l}\text { Використання } \\
\text { соціальних медіа }\end{array}$ & $\begin{array}{l}\text { Використання } \\
\text { соціальних медіа }\end{array}$ & $\begin{array}{l}\text { Веб-сайт має по- } \\
\text { силання } 3 \text { пере- } \\
\text { ходом на профілі } \\
\text { соціальних ме- } \\
\text { реж* }\end{array}$ & $\begin{array}{l}\text { Використання } \\
\text { 3D принтерів* }\end{array}$ \\
\hline 8 & $\begin{array}{l}\text { ЕRP-система для } \\
\text { обміну інформа-цією } \\
\text { між різни-ми } \\
\text { функціональ-ними } \\
\text { областями }\end{array}$ & $\begin{array}{l}\text { Купівля серед- } \\
\text { ніх-високих сер- } \\
\text { вісів телефонних } \\
\text { центрів } \\
\text { (CC services)* }\end{array}$ & $\begin{array}{l}\text { C пакет програ- } \\
\text { много забезпе- } \\
\text { чення ERP для } \\
\text { обміну iнфор- } \\
\text { мацією між різ- } \\
\text { ними функціо- } \\
\text { нальними облас- } \\
\text { тями* }\end{array}$ & $\begin{array}{l}\text { Купівля серед- } \\
\text { ніх-високих сер- } \\
\text { вісів телефонних } \\
\text { центрів } \\
\text { (CC services)* }\end{array}$ & $\begin{array}{l}\text { Купівля серед- } \\
\text { ніх-високих сер- } \\
\text { вісів телефонних } \\
\text { центрів } \\
\text { (CC services)* }\end{array}$ \\
\hline 9 & Мають CRM си-стему & $\begin{array}{l}\text { Надсилання еле- } \\
\text { ктронних рахун- } \\
\text { ків В2BG (авто- } \\
\text { матизоване опра- } \\
\text { цювання) * }\end{array}$ & $\begin{array}{l}\text { Мають CRM си- } \\
\text { стему* }\end{array}$ & $\begin{array}{l}\text { Надсилання еле- } \\
\text { ктронних рахун- } \\
\text { ків (автоматизо- } \\
\text { ване опрацюван- } \\
\text { ня)* }\end{array}$ & $\begin{array}{l}\text { Надсилання еле- } \\
\text { ктронних рахун- } \\
\text { ків (автоматизо- } \\
\text { ване опрацював- } \\
\text { ння) }\end{array}$ \\
\hline 10 & $\begin{array}{l}\text { Обмін інформа-цією } \\
\text { (УЛП) еле-ктронним } \\
\text { шля-хом } 3 \text { постачаль- } \\
\text { никами або клі- } \\
\text { єнтами }\end{array}$ & $\begin{array}{l}\text { Оплата реклами } \\
\text { в Інтернеті* }\end{array}$ & $\begin{array}{l}\text { Обмін інформа- } \\
\text { цією щодо керу- } \\
\text { вання ланцюга- } \\
\text { ми поставок } \\
\text { електронним } \\
\text { шляхом } 3 \text { інши- } \\
\text { ми підприємст- } \\
\text { вами, постачаль- } \\
\text { никами, клієнта- } \\
\text { ми* }\end{array}$ & $\begin{array}{l}\text { Оплата реклами } \\
\text { в Інтернеті* }\end{array}$ & $\begin{array}{l}\text { Використання } \\
\text { промислових або } \\
\text { сервісних робо- } \\
\text { тів (не обов'яз- } \\
\text { ково)* }\end{array}$ \\
\hline
\end{tabular}


Закінчення таблиці 7

\begin{tabular}{|c|c|c|c|c|c|c|}
\hline 1 & \multicolumn{2}{|r|}{2} & 3 & 4 & 5 & 6 \\
\hline 11 & \multicolumn{2}{|c|}{$\begin{array}{l}\text { Використовува-ли } \\
\text { будь-які ком-п'ютерні } \\
\text { мережі для продажів } \\
\text { (принаймні 1\%) }\end{array}$} & $\begin{array}{l}\text { Використовува- } \\
\text { ли будь-які ком- } \\
\text { п'ютерні мережі } \\
\text { для продажів } \\
\text { (принаймні } 1 \% \text { ) }\end{array}$ & $\begin{array}{l}\text { Використовува- } \\
\text { ли будь-які ком- } \\
\text { п'ютерні мережі } \\
\text { для продажів } \\
\text { (принаймні } 1 \% \text { ) }\end{array}$ & $\begin{array}{l}\text { Використовува- } \\
\text { ли будь-які ком- } \\
\text { п'ютерні мережі } \\
\text { для продажів } \\
\text { (принаймні 1\%) }\end{array}$ & $\begin{array}{l}\text { Використовува- } \\
\text { ли будь-які ком- } \\
\text { п'ютерні мережі } \\
\text { для продажів } \\
\text { (принаймні 1\%) }\end{array}$ \\
\hline 12 & \multicolumn{2}{|c|}{ 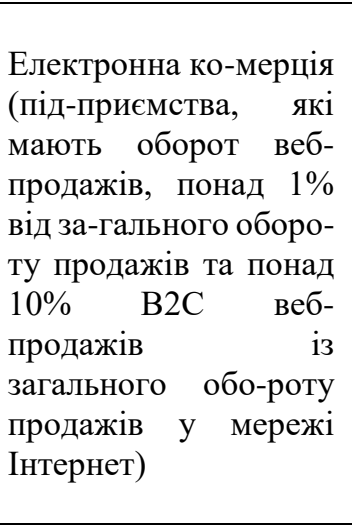 } & 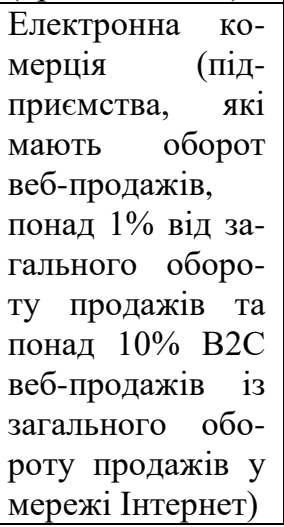 & 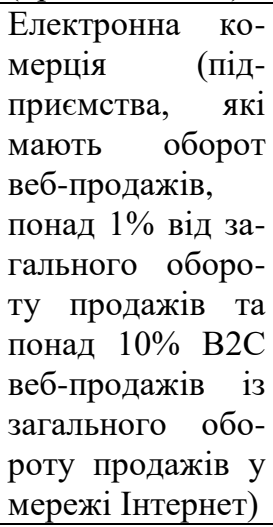 & 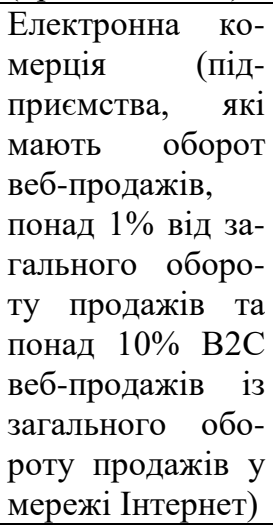 & $\begin{array}{l}\text { Аналіз великих } \\
\text { даних } \\
\text { якого будь- } \\
\text { джерела } \\
\text { даних (не обо- } \\
\text { в'язково) }\end{array}$ \\
\hline \multicolumn{2}{|c|}{ П_цт_дн } & \multicolumn{5}{|c|}{$\begin{array}{l}\text { Підприємства, що мають дуже низький індекс цифрової інтенсивності. } \\
\text { Кількість підприємств з балами від } 0 \text { до } 3\end{array}$} \\
\hline \multicolumn{2}{|c|}{ П_цТ_н } & \multicolumn{5}{|c|}{$\begin{array}{l}\text { Підприємства, що мають низький індекс цифрової інтенсивності. } \\
\text { Кількість підприємств з балами від } 4 \text { до } 6\end{array}$} \\
\hline \multicolumn{2}{|c|}{ П_цТ_в } & \multicolumn{5}{|c|}{$\begin{array}{l}\text { Підприємства, що мають високий індекс цифрової інтенсивності. } \\
\text { Кількість підприємств з балами від } 7 \text { до } 9\end{array}$} \\
\hline \multicolumn{2}{|c|}{ П_цт_дв } & \multicolumn{5}{|c|}{$\begin{array}{l}\text { Підприємства, що мають дуже високий індекс цифрової інтенсивності. } \\
\text { Кількість підприємств } 3 \text { балами від } 10 \text { до } 12\end{array}$} \\
\hline
\end{tabular}

*3міни порівняно з попереднім роком.

*Changes from the previous year.

Щодо статистики по країнах $\mathrm{CC}$, то можна зазначити, що лише п'ята частина компаній має високий рівень Індексу цифрової інтенсивності. Проте дані результати $є$ диверсифікованими по різних країнах. У Данії половина компаній працюють 3 високою цифровою інтенсивністю, а у Болгарії та Румунії - менше ніж кожна десята компанія працює над цифровою трансформацією [9].

У таблиці 8 наведено ступінь та швидкість проникнення цифрових технологій у бізнес. Великі компанії є більш цифровими аніж МСП.

\section{Таблиця 8}

Швидкість проникнення різноманітних цифрових технологій у бізнес країн ЄС у 2018 році

Table 8

The speed of various digital technologies penetration into EU countries business in 2018

\begin{tabular}{|c|c|c|c|c|c|}
\hline \multirow{2}{*}{$\begin{array}{c}\text { Ключові показники, що відображають } \\
\text { процеси цифрової трансформації }\end{array}$} & \multirow{2}{*}{ Рік } & \multicolumn{2}{|c|}{$\begin{array}{c}\text { \% підприємств } \\
\text { СС28 }\end{array}$} & \multicolumn{2}{|c|}{ 3міна } \\
\cline { 3 - 6 } & & Великі & МСП & Великі & МСП \\
\hline 1 & 2 & 3 & 4 & 5 & 6 \\
\hline Наявність веб-сайту або домашньої сторінки & 2017 & $94 \%$ & $76 \%$ & 0 & 2 \\
\hline
\end{tabular}


Закінчення таблиці 8

\begin{tabular}{|l|c|c|c|c|c|}
\hline \multicolumn{1}{|c|}{1} & 2 & 3 & 4 & 5 & 6 \\
\hline Веб-сайт має деякі інтерактивні функції & 2017 & $74 \%$ & $58 \%$ & 2 & 3 \\
\hline Використовують соціальні мережі & 2017 & $72 \%$ & $47 \%$ & 9 & 8 \\
\hline $\begin{array}{l}>50 \% \text { зайнятих користуються комп'ютерами } \\
\text { та Інтернетом }\end{array}$ & 2017 & $50 \%$ & $40 \%$ & 3 & 2 \\
\hline $\begin{array}{l}\text { Найшвидше широкосмугове з'єднання } \\
\text { становить не менше 30 Мб/с }\end{array}$ & 2017 & $69 \%$ & $37 \%$ & 15 & 12 \\
\hline $\begin{array}{l}\text { Використовують програмне забезпечення } \\
\text { ЕRР (планування ресурсів підприємства) }\end{array}$ & 2017 & $76 \%$ & $33 \%$ & $\begin{array}{c}\text { Ності порівняти } \\
\text { вом 2015 роком }\end{array}$ \\
\hline $\begin{array}{l}\text { Використовують інформаційну систему } \\
\text { управління відносинами з клієнтами (СRМ) }\end{array}$ & 2017 & $62 \%$ & $32 \%$ & 0 & 1 \\
\hline $\begin{array}{l}\text { >20\% працівників із портативними } \\
\text { пристроями для комерційного використання }\end{array}$ & 2017 & $38 \%$ & $32 \%$ & 7 & 5 \\
\hline Використовують послуги спеціалістів з ІКТ & 2017 & $75 \%$ & $18 \%$ & -3 & -1 \\
\hline Продаж онлайн (принаймні 1\% від обороту) & 2017 & $39 \%$ & $17 \%$ & 1 & 1 \\
\hline $\begin{array}{l}\text { Обмінюватися даними електронного } \\
\text { управління ланцюгами поставок }\end{array}$ & 2017 & $47 \%$ & $17 \%$ & -1 & 1 \\
\hline $\begin{array}{l}\text { Електронні продажі в секторі (В2С) бізнес- } \\
\text { споживач }\end{array}$ & 2017 & $9 \%$ & $7 \%$ & 1 & 1 \\
\hline
\end{tabular}

Соціальні медіа, електронні рахунки, мобільні додатки та швидке широкосмугове з'єднання є рушійною силою для цифрової трансформації європейських підприємств. Хмарні обчислення також показують високі темпи зростання, але поки тільки на великих підприємствах.

У нашій країні немає загальної оцінки для усіх бізнес-структур. Зважаючи на те, що Україна не відображається у багатьох глобальних рейтингах щодо розвитку цифрової економіки, виникає проблема з розумінням загальної картини щодо використовуваної цифрової інфраструктури, точок перетину та інтеграції з бізнес-структурами, органами влади та ін. Основною причиною $є$ те, що у нас відсутнє інформаційне поле, так звані дорожні карти для бізнесу, які б рекомендували та інформували бізнес про ті чи інші цифрові продукти. Відсутня чітка та зрозуміла статистична методологія й статистичні спостереження для отримання актуальних даних щодо цифрового розвитку бізнесструктур та цифрової економіки країни в цілому.

Основним джерелом даних у нашій країні є Держстатистика, яка збирає дані 3 розробленої уніфікованої форми (ф. № 1-ІКТ (річна) «Використання інформаційнокомунікаційних технологій на підприємствах у $20 \_$році») [10].

У 2017 році наша країна взяла за основу європейську форму статистичних спостережень «Опитування щодо використання IКТ та Е-комерції на підприємствах» (Community survey on ICT usage and E-commerce in enterprises) для наповнення індексу DESI складової №4 «Інтеграція цифрових технологій бізнесом».

Для отримання актуальної інформації стосовно розвитку цифрової економіки та суспільства країн ЄС, Європейська Комісія постійно модифіковує індикатори, що входять до структури індексу DESI. Бізнес-суб'єкти ЄC, а саме малі, середні та великі підприємництва проходять дане статистичне опитування щорічно. 
Для того, щоб наша країна інтегрувалася у відповідні глобальні індекси, необхідно уніфікувати статистичну групу індикаторів (показників), проте потрібно врахувати розрив, який існує між суб'єктами вітчизняного та європейського бізнесу.

Незважаючи на те, що із запланованих заходів «Концепції розвитку цифрової економіки та суспільства України на 2018-2020 роки» зроблено мало, уряд нашої країни декларує плани щодо позицій нашої країни у даних глобальних рейтингах (табл. 9).

\section{Таблиця 9}

Прогнозовані позиції нашої країни у глобальних рейтингах у 2025 році

Table 9

Predicted position of our country in global rankings in 2025

\begin{tabular}{|c|l|c|c|c|c|}
\hline $\begin{array}{c}\text { № } \\
3 / \Pi\end{array}$ & \multicolumn{1}{|c|}{ Назва показника } & $\begin{array}{r}\text { Позиція у } \\
\text { рейтингу } \\
(2016 \text { р.) }\end{array}$ & $\begin{array}{c}\text { Позиція у } \\
\text { рейтингу } \\
(2020 \text { р.) }\end{array}$ & $\begin{array}{c}\text { Позиція у } \\
\text { рейтингу } \\
(2025 \text { р. })\end{array}$ & $\begin{array}{c}\text { Зростання 3 } \\
\text { 2016 року }\end{array}$ \\
\hline 1 & $\begin{array}{l}\text { Digital Economy and Society } \\
\text { Index 2025 (EU) }\end{array}$ & - & № 20 & № 20 & $\begin{array}{c}\text { Включення у } \\
\text { даний рейтинг }\end{array}$ \\
\hline 2 & $\begin{array}{l}\text { Global Innovation Index 2025 } \\
\text { (GII, INSEAD WIPO) }\end{array}$ & 56 & 40 & 15 & 41 \\
\hline 3 & $\begin{array}{l}\text { Networked Readiness Index } \\
\text { 2025 (WEF) }\end{array}$ & 64 & 30 & 20 & 44 \\
\hline 4 & $\begin{array}{l}\text { Broadband Penetration Index } \\
\text { 2025 (ITU) }\end{array}$ & - & - & 20 & Вкл. у рейтинг \\
\hline 5 & $\begin{array}{l}\text { Global Competitiveness Index } \\
\text { 2025 (WEF) }\end{array}$ & 85 & 60 & 20 & 65 \\
\hline
\end{tabular}

Для успішної імплементації цифрового порядку денного та досягнення відповідних позицій, перш за все необхідно сформувати адекватну систему індикаторів, що відображатимуть, у тому числі ефективність упровадження та поширення цифрових технологій в економіці України. Для цього необхідно сформувати надійні індикатори розвитку.

Саме тому в таблиці 10 виокремлено основні причини чому Україні варто врахувати практику $\mathrm{CC} \mathrm{у} \mathrm{розробленні} \mathrm{методології} \mathrm{збирання} \mathrm{та} \mathrm{опрацювання}$ статистичної інформації (статистичних даних). На основі цього необхідно розробити власну методологію визначення індексу цифрової трансформації бізнесу, яка б враховувала реалії та специфіку вітчизняного ринку й відображала глибше та якісніше розуміння процесів цифровізації вітчизняного бізнес-середовища. 


\section{Таблиця 10}

Необхідність розроблення методології визначення індексу цифрової трансформації бізнесу

Table 10

Necessity of the development of methodology for determining the digital business transformation index

\begin{tabular}{|c|c|c|c|}
\hline $\begin{array}{l}\text { № } \\
3 / \Pi\end{array}$ & $\begin{array}{c}\text { Причини, чому } \\
\text { Україні варто } \\
\text { врахувати практику } \\
\text { ЄС із забору } \\
\text { статистичних даних } \\
\text { («Community survey } \\
\text { on ICT usage and } \\
\text { E-commerce in } \\
\text { enterprises») }\end{array}$ & $\begin{array}{c}\text { Недоліки, які не враховані } \\
\text { (ф. № 1-ІКТ (річна) } \\
\text { «Використання } \\
\text { інформаційно- } \\
\text { комунікаційних технологій } \\
\text { на підприємствах } \\
\text { у } 20 \_ \text {році» }\end{array}$ & $\begin{array}{c}\text { Причини необхідності } \\
\text { розроблення власної } \\
\text { методології визначення } \\
\text { індексу цифрової } \\
\text { трансформації бізнесу }\end{array}$ \\
\hline 1 & 2 & 3 & 4 \\
\hline 1 & $\begin{array}{l}\text { Країни СС першочер- } \\
\text { гово мотивують біз- } \\
\text { нес-структури до ви- } \\
\text { користання новітніх } \\
\text { цифрових технологій. } \\
\text { Створили відповідну } \\
\text { еко-систему, в якій усі } \\
\text { використовують IT } \\
\text { інфраструктуру (осві- } \\
\text { та, бізнес, влада, ме- } \\
\text { дицина та ін.) }\end{array}$ & $\begin{array}{l}\text { Не проводять опитування та } \\
\text { забір даних мікро- } \\
\text { підприємств. Саме мікро- } \\
\text { підприємства (в тому числі } \\
\text { стартапи) використовують } \\
\text { цифрові технології - при } \\
\text { старті власної справи й } \\
\text { завдяки цьому функціо- } \\
\text { нують ефективно }\end{array}$ & 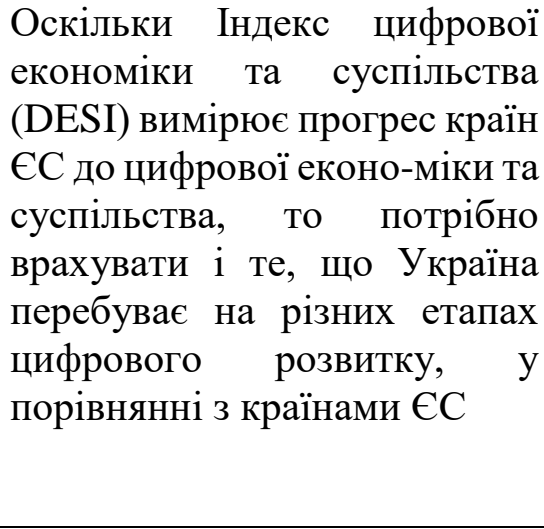 \\
\hline 2 & $\begin{array}{l}\text { Кожного року форма } \\
\text { переглядається і мо- } \\
\text { дифікується під най- } \\
\text { більш актуальні та } \\
\text { важливі технології }\end{array}$ & $\begin{array}{l}\text { Розрив між цифровою } \\
\text { грамотністю європейського } \\
\text { та вітчизняного бізнесу. Не } \\
\text { зрозумілість термінології та } \\
\text { більшості новітніх техно- } \\
\text { логій }\end{array}$ & $\begin{array}{l}\text { Необхідне комплексне оці- } \\
\text { нювання усіх суб'єктів } \\
\text { бізнесу. При цьому необхід- } \\
\text { но враховувати актуальний } \\
\text { стан цифрової трансформації } \\
\text { бізнесу }\end{array}$ \\
\hline 3 & $\begin{array}{l}\text { Прозорість та зрозумі- } \\
\text { лість рівня розвитку } \\
\text { бізнес-структур тієї чи } \\
\text { іншої країни }\end{array}$ & $\begin{array}{l}\text { Не готовність вітчизняного } \\
\text { бізнесу інтегрувати техно- } \\
\text { логії Індустрії } 4.0 ; \quad \text { не } \\
\text { спробувавши } \\
\text { Індустрії } 3.0 .\end{array}$ & $\begin{array}{l}\text { Завдяки ефективному вико- } \\
\text { ристанню цифрових техно- } \\
\text { логій зникає розрив між } \\
\text { розвитком МСП та великими } \\
\text { суб'єктами }\end{array}$ \\
\hline 4 & $\begin{array}{l}\text { Дані базуються на } \\
\text { поєднанні державної } \\
\text { та відомчої статисти- } \\
\text { ки із системою періо- } \\
\text { дичних представниць- } \\
\text { ких опитувань населе- } \\
\text { ння, професійних груп } \\
\text { i підприємств, що } \\
\text { виконуються профе- } \\
\text { сійними соціологічни- } \\
\text { ми організаціями }\end{array}$ & $\begin{array}{l}\text { Використання даних лише } 3 \\
\text { одного джерела Державної } \\
\text { статистики }\end{array}$ & $\begin{array}{l}\text { Мотивування суб'єктів під- } \\
\text { приємництва до використан- } \\
\text { ня нових цифрових техноло- } \\
\text { гій }\end{array}$ \\
\hline
\end{tabular}


Закінчення талиці 10

\begin{tabular}{|c|c|c|c|}
\hline 1 & 2 & 3 & 4 \\
\hline 5 & & & $\begin{array}{l}\text { Дороговкази, інформаційне } \\
\text { джерело та здатність визна- } \\
\text { чити власний індекс цифро- } \\
\text { вої трансформації й отрима- } \\
\text { ти рекомендації щодо підви- } \\
\text { щення рівня цифрової } \\
\text { зрілості }\end{array}$ \\
\hline 6 & & & $\begin{array}{l}\text { Прозорість та зрозумілість } \\
\text { алгоритму імплементації від- } \\
\text { повідних технологій у власну } \\
\text { бізнес-діяльність для суб’єк- } \\
\text { та підприємництва }\end{array}$ \\
\hline 7 & & & $\begin{array}{l}\text { Усунення «інформаційної } \\
\text { нерівності» між окремими } \\
\text { регіонами, галузями економі- } \\
\text { ки та різними верствами } \\
\text { населення }\end{array}$ \\
\hline
\end{tabular}

Висновки. Досліджено основні глобальні метрики оцінювання розвитку цифрової економіки в країнах $\mathrm{CC}$ та визначено позиції нашої країни. Проведено глибинний аналіз метрик оцінювання цифрової трансформації бізнес-структур. У майбутній версії статті буде розроблено інноваційну методику визначення Індексу цифрової трансформації для вітчизняних бізнес-структур.

Conclusions. The main global metrics for assessing the development of the digital economy in EU countries are investigated and our country's ranking is determined in this paper. In-depth analysis of the metrics for assessing the digital business structures transformation is carried out. The innovative methodology for determining the Digital Transformation Index for domestic business structures will be developed in the paper future version.

\section{Список використаної літератури}

1. Цифрова адженда України - 2020. URL: https:/ucci.org.ua/uploads/files/58e78ee3c3922.pdf (дата звернення: 28.10.2019).

2. Про схвалення Концепції розвитку цифрової економіки та суспільства України на 2018-2020 роки. URL: https://www.kmu.gov.ua/ua/npas/pro-shvalennya-koncepciyi-rozvitku-cifrovoyi-ekonomiki-tasuspilst va-ukrayini-na-20182020-roki-ta-zatverdzhennya-planu-zahodiv-shodo-yiyi-realizaciyi (дата звернення: 28.10.2019).

3. Global Competitiveness Index (GCI (WEF) 2018. URL: https://reports.weforum.org/globalcompetitiveness-report-2018/ (accessed: 28.10.2019).

4. Global innovation index 2018. URL: https://www.wipo.int/edocs/pubdocs/en/wipo_pub_gii_2018.pdf (accessed: 30.10.2019).

5. Networked Readiness Index (NRI (WEF). URL: https://www.statista.com/statistics/267540/ranking-ofcountries-networked-readiness-index/ (accessed: 30.10.2019).

6. Broadband Penetration Index (ITU) 2018. URL: https://www.itu.int/dms_pub/itu-s/opb/pol/S-POLBROAD BAND.19-2018-PDF-E.pdf (accessed: 30.10.2019).

7. World Digital Competitiveness (WDC) ranking 2018. URL: file://C:/Users/user/Downloads/wcy_ methodology_2019.pdf (accessed 30.10.2019).

8. Digital Economy and Society Index. URL: https://ec.europa.eu/digital-single-market/en/news/digitaleconomy-and-society-index-2018-report (accessed 30.10.2019).

9. Цифрова трансформація. URL: https://uk.wikipedia.org/wiki/Цифрова_трансформація (дата звернення: 30.10 .2019$)$. 
10. Статистичнй бюлетень «Використання інформаційно-комунікаційних технологій на підприємствах України» / Державна служба статистики України; ред. І. В. Калачова. К.: Державна служба статистики України, 2017. 30 с. (дата звернення: 06.12.2019).

11. Eurostat community survey ict usage and e-commerce in enterprises. URL: https://ec.europa.eu/eurostat/ statistics-explained/index.php/E-commerce_statistics (дата звернення: 15.12.2019).

\section{References}

1. Tsyfrova adzhenda Ukrainy - 2020. URL: https://ucci.org.ua/uploads/files/58e78ee3c3922.pdf (data zvernennia: 28.10.2019).

2. Pro skhvalennia Kontseptsii rozvytku tsyfrovoi ekonomiky ta suspilstva Ukrainy na 2018-2020 roky: vebsait. URL: https://www.kmu.gov.ua/ua/npas/pro-shvalennya-koncepciyi-rozvitku-cifrovoyi-ekonomiki-tasuspilst va-ukrayini-na-20182020-roki-ta-zatverdzhennya-planu-zahodiv-shodo-yiyi-realizaciyi (data zvernennia: 28.10.2019).

3. Global Competitiveness Index (GCI (WEF) 2018. URL: https://reports.weforum.org/globalcompetitiveness-report-2018/ (accessed: 28.10.2019).

4. Global innovation index 2018. URL: https://www.wipo.int/edocs/pubdocs/en/wipo_pub_gii_2018.pdf (accessed: 30.10.2019).

5. Networked Readiness Index (NRI (WEF). URL: https://www.statista.com/statistics/267540/ranking-ofcountries-networked-readiness-index/ (accessed: 30.10.2019).

6. Broadband Penetration Index (ITU) 2018. URL: https://www.itu.int/dms_pub/itu-s/opb/pol/S-POLBROADBAND.19-2018-PDF-E.pdf (accessed: 30.10.2019).

7. World Digital Competitiveness (WDC) ranking 2018. URL: file://C:/Users/user/Downloads/ wcy_methodology_2019.pdf (accessed: 30.10.2019).

8. Digital Economy and Society Index. URL: https://ec.europa.eu/digital-single-market/en/news/digitaleconomy-and-society-index-2018-report (accessed: 30.10.2019).

9. Tsyfrova transformatsiia: veb-sait. URL: https://uk.wikipedia.org/wiki/Tsyfrova_transformatsiia (data zvernennia: 30.10.2019).

10. Statystychnyi biuleten «Vykorystannia informatsiino-komunikatsiinykh tekhnolohii na pidpryiemstvakh Ukrainy» / Derzhavna sluzhba statystyky Ukrainy; red. I. V. Kalachova. K.: Derzhavna sluzhba statystyky Ukrainy, 2017. 30 p. (data zvernennia: 06.12.2019).

11. Eurostat community survey ict usage and e-commerce in enterprises. URL: https://ec.europa.eu/eurostat/ statistics-explained/index.php/E-commerce_statistics (data zvernennia: 15.12.2019). 